\title{
Ficção Especulativa 2018.1
}

Matheus Felipe Xavier de Oliveira

Não somente a estrutura geofísica do Planeta Terra tem sido significativamente afetada pelo ser humano nas últimas décadas, levando pesquisadores a denominarem o atual intervalo de tempo geológico como Antropoceno, mas também a psicosfera circundante — configurada pela profusão de mutações socioculturais e históricas desse tempo. Parece uma tarefa labiríntica apontar o momento da história em que essas transformações se tornaram mais vertiginosas. E a importância dessa dúvida parece se desmanchar ante a impressão cada vez mais pungente de que tal momento não seria único, mas uma multiplicidade de instantes deslocando-se pelo tempo em caráter circular; e que estes se atravessam e se aglomeram dentre um amplo espectro entre dois pontos, ambos obscuros.

O começo, antes da língua e da cultura, mesmo dos próprios humanos; e o inelutável fim, se não o primeiro ou o definitivo, mas aquele que NOS afligirá.

Em um cenário onde o pensamento capitalista, indústria cultural e a tecnociência materializam-se em instituições como grandes bancos, multinacionais, ONU, FMI, Hollywood, agências de pesquisa etc. ditando e controlando os ensejos humanos para fins escusos; suspeitar de qualquer informação entregue facilmente é só uma primeira medida de redução de danos e o começo de uma tática de resistência. Iniciativas empreendidas a partir do meio do século XX, tais como a criação dos primeiros computadores, o uso de substâncias provenientes de plantas psicotrópicas originários de culturas ancestrais em experimentos que sondavam os limites do inconsciente humano, e as implícitas relações dessas com outros episódios de destaque nesse período - como a criação de armas de destruição em massa e contatos alienígenas (The Roswell UFO Incident) —, se analisadas em conjunto parecem apontar para um caminho conspiratório maquinado por grupos ${ }^{1}$, para os quais essa sensação pairante de medo, torpor e engano parece constituir uma trama de interesse. Alguns resultados dos esforços empregados nesse aparente "projeto", sobretudo aqueles relacionados com o desenvolvimento do pensamento em rede, são o Memex e o conceito imagético de Xanadu ${ }^{2}$, uma biblioteca eletrônica universal em satélites em órbita estacionária que poderia ser acessada de qualquer ponto da Terra constituindo um ponto de diálogo entre toda a humanidade em todos os tempos - algo que como a Biblioteca de Babel, ideia de Jorge Luís Borges ${ }^{3}$. Em perspectiva, tais conceitos parecem confluir para um grande desejo em desenvolver "canais de comunicação" em um dado ponto que culminaria no despertar da consciência da própria Terra, de modo que todos os humanos se conectassem em rede e ressoassem na mesma frequência, seguindo um modelo neural. Entretanto, o interesse velado por trás desse desejo não parece convergir para um panorama onde a satisfação seja de fato global. Hoje, em tempos de uma internet, para o bem e para o mal, sabe-se abertamente que essas iniciativas de ataque, sequestro e manipulação de subjetividades esboçadas desde o período citado até hoje - e talvez agora perto de um potencial ainda mais ameaçador, que parece nos deixar sem saída compreendem o plano de um grande Deus transhumanista, que em outros termos, representaria o triunfo final das grandes corporações. 
À vista disso, os movimentos que rompem com a lógica imperialista, como o afrofuturismo e aqueles em torno da decolonização, em todo seu potencial de catalisar a redescoberta da ontologia dos povos tidos como subalternos, o sonhar livre e a construção de novas narrativas no sentido de um futuro diferente daquele que vem sendo arquitetado para a humanidade e para a Terra - Gaia — são de grande valor, não somente como alternativa, mas exercendo um caráter antagônico ao projeto das grandes corporações. É desejável que esses movimentos continuem a quebrar com as imposições do pensamento colonial sobre seus corpos, e, para, além disso, intercedam com especial cuidado por uma porção substancial desse novo projeto de futuro, as crianças, em especial as suas próprias. Esses corpos de extrema vulnerabilidade são sistematicamente abusados moralmente, fisicamente e sexualmente; e parece ser uma tendência o desrespeito a seus direitos e natureza, assim como a invisibilização dessas questões, mesmo nos movimentos periféricos. Nesse conflito que atravessa nossa época, são as crianças que estão expostas aos maiores perigos, em uma instância que certamente atinge o campo metafísico das coisas. Na animação japonesa de 1998, Serial Experiments Lain ${ }^{4}$, uma ficção científica que anunciadamente gira em torno dos propósitos encabeçados pelo transhumanismo de criar um

"cérebro global", a protagonista se encontra com o idealizador de um experimento que dialoga com outros já citados, como o Memex e o Xanadu, e visa explorar as habilidades psíquicas natas dos seres humanos, adormecidas a medida que amadurecem. Ele desenvolveu um dispositivo chamado KIDS, que coletava e amplificava poderes de grupos de crianças para a manipulação da realidade. A pesquisa teria sido roubada e aprimorada, ocasionando eventos macabros que desordenariam a realidade. A citação desse enredo ficcional é usada aqui como ponto de enlace das tramas abordadas no texto, chamando a atenção para um problema latente e urgente: o grande número de desaparecimento de crianças pelo mundo, que indica a existência de uma ampla rede de tráfico de pessoas (sim, crianças são pessoas) e uma indústria do abuso sexual infantil. É difícil determinar os números exatos, mas somente no Brasil são registrados cerca de 50 mil casos por ano. Mundialmente, a quantidade de casos é ainda mais difícil de ser apontada, mas atingiria os milhões ${ }^{5}$ Basta uma pequena pesquisa mesmo na camada mais superficial da internet para se ter acesso à grandes casos de repercussão mundial, escândalos envolvendo políticos e personalidades famosas, tratados como fake news ou "conspiração política", a exemplo do Pizza Gate 6 . Mesmo as estatísticas já sendo alarmantes, elas de fato ainda não mostram a verdadeira dimensão do problema, principalmente em países de continentes periféricos, como África e América Latina.

Há muito ainda que a se acrescentar; falar e fazer a respeito; nesse sentido, o presente texto visa endossar a urgência dessa questão, e como sua permanência em uma posição de tabu é preocupante e serve a um grande programa de controle das massas e poder para poucos. Assim, parece inconcebível pensar em um futuro livre do obscurantismo que acompanhou a humanidade até aqui, sem antes descortinar tudo que envolve essa mácula: as operações, câmbios, negócios, seitas, rituais, grupos e projetos ocultos de um sistema construído sobre uma pilha de corpos.

1 -http://www.oarquivo.com.br/extraordinario/ufologia/1237-o-projetomajestic-12.html 2 -https://hipertextualize.wordpress.com/2012/06/14/projetoxanadu-memex-e-nsl/ 3 -http://site.ufvim.edu.br/cafeliterario/a-bibliotecade-babel-jorge-luis-borges/ 4 
-http://www.finisgeekis.com/2016/10/18/3-passos-para-entender-serial-experiments-

lain/5 -http://www.childhood.org.br/unicef-criancas-estao-entre-as-maiores-vitimas-detrafico-pessoas

6-

https://en.wikipedia.org/wiki/Pizzagate conspiracy theory 